\title{
PITYPHYLLUM MERCEDES-ABARCAE (MAXILLARIINAE) A NEW SPECIES FROM ECUADOR
}

\author{
Leisberth Vélez-Abarca ${ }^{1,5,6}$, Marco M. Jiménez ${ }^{1,2,5}$, Juan Sebastián Moreno $^{3}$ \\ \& LUIS E. BAQUERO ${ }^{1,4}$
}

${ }^{1}$ Grupo Científico Calaway Dodson: Investigación y Conservación de Orquídeas del Ecuador, Quito, 170510, Pichincha, Ecuador

${ }^{2}$ Vivero de Conservación La Paphinia, Avenida del Ejército y Juan Izquierdo, Zamora, Zamora Chinchipe, 190102, Ecuador

${ }^{3}$ Grupo de Investigación Schultes, Fundación Ecotonos, Cali, Colombia

${ }^{4}$ Grupo de Investigación en Biodiversidad, Medio Ambiente y Salud BIOMAS. Carrera de Ingeniería Agroindustrial y Alimentos. Facultad de Ingeniería y Ciencias Agropecuarias, Universidad de Las

Américas, Calle José Queri, Quito, Pichincha, 170137

${ }^{5}$ Associazione Orchidofili Centro Italia, Treglio (Ch), Abruzzo, Italia

${ }^{6}$ Author for correspondence: leis.alexis92@gmail.com

\begin{abstract}
A new species of Pityphyllum from south-eastern Ecuador was found during an investigation of the orchids of the Cordillera del Cóndor. Pityphyllum mercedes-abarcae is described and illustrated. Information concerning its distribution, habitat, and phenology is provided. The new proposed taxon is morphologically similar to $P$. pinoides, from which it differs by the smaller plants, the spathulate petals with an erose margin in the middle third, lip flattened is square in the middle third, wedge in the basal third, and acute in the apical third with two small parallel calluses in the apical third, presents a slight cell thickening in the abaxial part of the apical third and elongated trichomes below the stigma.
\end{abstract}

Resumen. Una nueva especie de Pityphyllum del sureste de Ecuador fue encontrada durante una investigación sobre las orquídeas de la Cordillera del Cóndor. Pityphyllum mercedes-abarcae se describe e ilustra. Se proporciona información sobre la distribución, el hábitat y la fenología de esta especie. El nuevo taxón propuesto es morfológicamente similar a $P$. pinoides del cual se diferencia por las plantas más pequeñas, los pétalos espatulados con el margen eroso en el tercio medio. El labelo aplanado es cuadrado en el tercio medio, cuneado en el tercio basal y agudo en el tercio apical con dos pequeños callos paralelos en el tercio apical, presenta un ligero engrosamiento celular en la parte abaxial del tercio apical del labelo y tricomas alargados debajo del estigma.

Key Words/Palabras clave: Andean tepuis, Cordillera del Cóndor, Pityphyllum pinoides, taxonomía, taxonomy, tepuyes andinos

Introduction. Maxillaria Ruiz \& Pav. (Ruiz \& Pavón 1794) is one of the most diverse genera in the Orchidaceae, distributed from Florida (United States) and Mexico to Peru, Brazil, Bolivia, and northern Argentina, including the Antilles (Zambrano et al. 2020). Molecular phylogenetic studies of the Maxillariinae Benth. have been carried out to delimit the generic circumscriptions within the subtribe (Ojeda et al. 2003, Singer \& Koehler 2003, Dathe \& Dietrich 2006, Sitko et al. 2006, Whitten et al. 2007). Blanco et al . (2007) proposed a generic realignment of Maxillariinae recognizing 17 genera, including Cryptocentrum Benth., Cyrtidiorchis Rauschert, Mormolyca Fenzl, and Pityphyllum Schltr.

Pityphyllum, one of these segregate genera, consists of eight species distributed in the high Andes of Bolivia, Colombia, Ecuador, Peru, and Venezuela (Dodson 2003, Whitten et al. 2006). The genus was established in 1920 by Rudolf Schlechter based on two materials collected: Pityphyllum laricinum (Kranzl.) 
Schltr. collected by Weberbauer in Peru and P. antioquiense by F.C. Lehmann near Carolina del Principe in the Department of Antioquia, Colombia; it was revised by Sweet (1972) and then expanded by Whitten et al. (2006). The plants are characterized by its epiphytic, pendulous plants, a much-branched rhizome, small pseudobulbs covered by a tunic fused to the pseudobulb ("outer sheath") with several apical leaves, the diminutive flowers borne from the axils of rhizome bracts between the pseudobulbs, the column foot practically nonexistent, and the capsules with apical dehiscence (Whitten et al. 2006, Blanco et al. 2007). Pityphyllum species are scarce plants (Dunsterville \& Dunsterville 1977), poorly represented in herbaria, and there are likely to be several undescribed species in this genus (Whitten et al. 2006). While investigating the orchids of the Cordillera del Cóndor, we found a new species of Pityphyllum, which we describe and illustrate here.

Material and methods. The description and illustrations of the new taxon were done from specimens collected during a comparative study on the orchids in an elevation gradient of the Cordillera del Cóndor. Some specimens were cultivated and photographed at the Vivero de Conservación La Paphinia in Zamora, Ecuador, under permits granted by the Ministerio del Ambiente de Ecuador. Photographs of individuals in flower were taken using a Panasonic $\mathbb{R}$ FZ300 camera with a Raynox DCR-250 mm lens. Prior publications on Pityphyllum were consulted and were compared to the new species described.

\section{TAXONOMIC TREATMENT}

\section{Pityphyllum mercedes-abarcae Vélez-Abarca \& M.M.Jiménez, sp. nov. (Fig. 1-2, 4).}

TYPE: Ecuador. Zamora Chinchipe: Cordillera del Cóndor flank, 1280 m, 24 Sep 2020, flowered in cultivation at 16 March 2020, L. Vélez LV0068 (holotype: ECUAMZ!)

Diagnosis: Similar to Pityphyllum pinoides H.R.Sweet. from which it differs by the smaller plants, bearing pseudobulbs at very short intervals, the pedunculate flowers are produced from the rhizome at the base of immature pseudobulbs; the ovary is elongated; the petals are spatulate, slightly oblique at the base, the margin is erose in the middle third; the lip flattened is square in the middle third, wedge in the basal third and acute in the apical third with two small parallel calluses; it presents a slight cell thickening in the abaxial part of the apical third of the lip. Also, this species shows a unique character in Pityphyllum, the elongated trichomes under the stigma.

Plant up to $8 \mathrm{~cm}$ tall, epiphytic, sparsely branched, descending. Roots slender, white, flexuous, 0.4-0.5 mm in diameter. Rhizome slender, arcuate at the base, bearing pseudobulbs at very short intervals, 0.4-1.2 cm. Pseudobulbs yellowish-green, ovoid to narrowly ovoid, apically subobtuse, 5.8$8.3 \times 2.1-2.6 \mathrm{~mm}$, inserted obliquely in the rhizome, slightly furrowed longitudinally, covered with hyaline sheaths, not foliaceous, old pseudobulbs lose their apical leaves. Leaves semiterete, acicular, acute, coriaceous, glabrous, slightly curved, dorsoventrally flattened, 3-4 leaves emerging from the apex of the pseudobulb, $11.0-24.0 \times 0.5-0.7 \mathrm{~mm}$. Inflorescence 1-flowered, produced from the rhizome at the base of immature pseudobulbs, pedunculated, $4.7 \mathrm{~mm}$ long; floral bract long-ovate, acuminate, elongated, scarious, pigmented with brown spots, enveloping the entire pedicel and ovary. Ovary elongated, semiterete, minutely furrowed, slightly curved at the apex, $4.6 \times 0.5 \mathrm{~mm}$. Flower white, semi-open, dorsal and lateral sepals unequal. Dorsal sepal narrowly elliptical, attenuate at the base, acute, $3.1 \times 1.1 \mathrm{~mm}$, concave in the proximal second third and convex in the distal third, 3-veined, minutely apiculate at the apex. Lateral sepals elliptical, constricted at the base, acute, concave below the middle, 3 -veined, $3.0 \times 1.2 \mathrm{~mm}$, minutely apiculate at the apex. Petals spathulate, slightly oblique at the base, apex minutely apiculate, the margin erose in the middle third, 1 -veined, $2.9 \times 0.9 \mathrm{~mm}$. Lip flattened is square in the middle third, wedge in the basal third and acute in the apical third, in its natural state it has a panduriform, trilobate, attenuate at the base, concave below the middle third with oblong, erect lateral lobes, apical lobe triangular with two small parallel calluses in the apical third, presents a slight cell thickening in the abaxial part of the apical third of the lip, apex shortly acuminate, recurved, $2.9 \times 1.4 \mathrm{~mm}$, inserted at the base of the column. Column claviform, slightly curved, $2.0-2.5 \mathrm{~mm}$ 


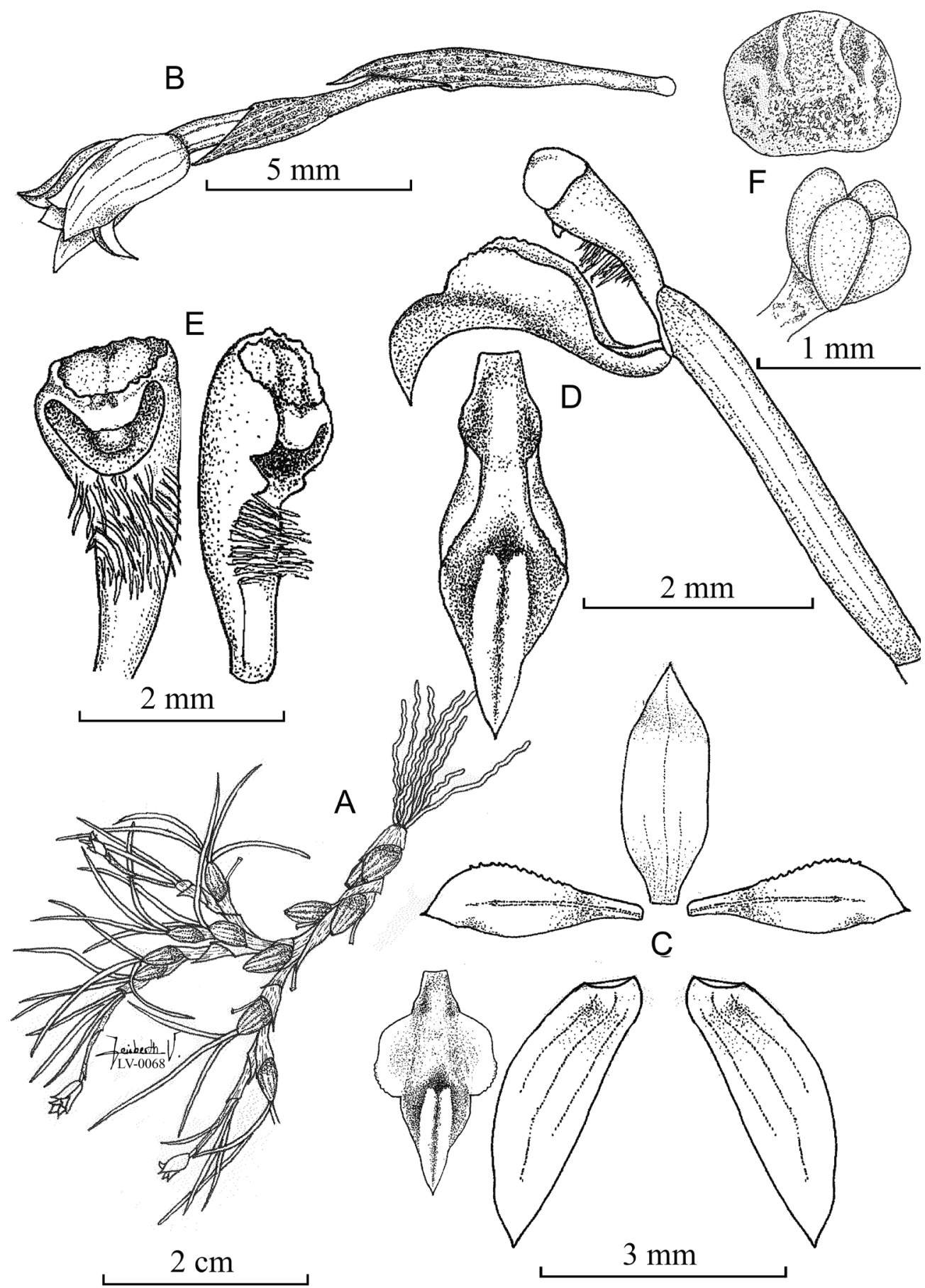

Figure 1. Pityphyllum mercedes-abarcae Vélez-Abarca \& M.M.Jiménez. A. Habit. B. Inflorescence and flower in lateral view. C. Dissected perianth. D. Part of the peduncle, pedicel, ovary, column and lip in lateral view and lip ventral view. E. Column in ventral and oblique view. F. Anther cap and pollinarium Illustration by Leisberth Vélez Abarca, based on the holotype, L. Vélez LV-0068 (ECUAMZ). 


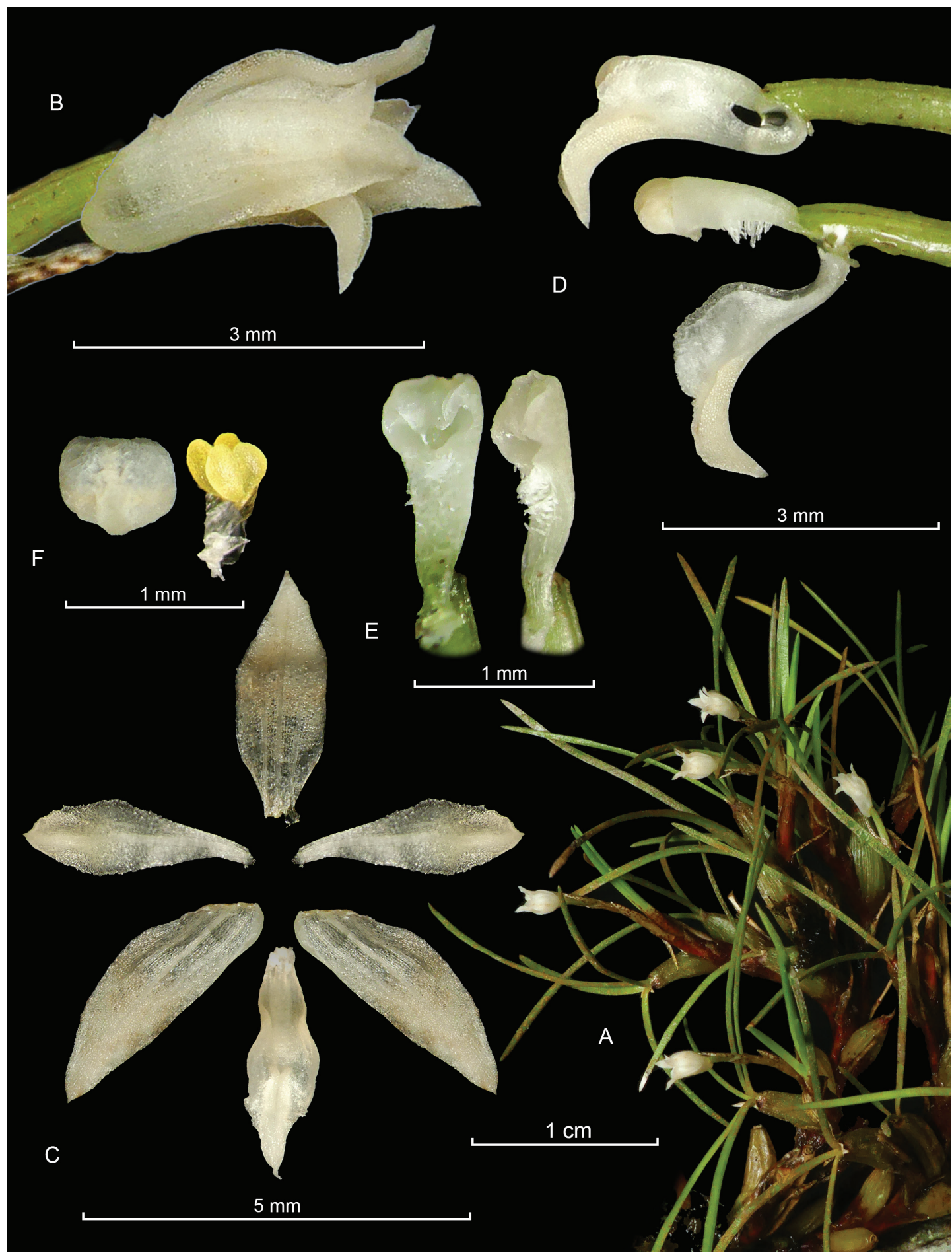

Figure 2. Pityphyllum mercedes-abarcae Vélez-Abarca \& M.M.Jiménez. A. Habit. B. Flower, lateral view. C. Dissected perianth. D. Ovary, column, and lip, lateral view. E. Column, ventral and oblique view. F. Anther cap and pollinarium. Lankester Composite Dissection Plate by Juan Sebastián Moreno from photos by Marco M. Jiménez. 


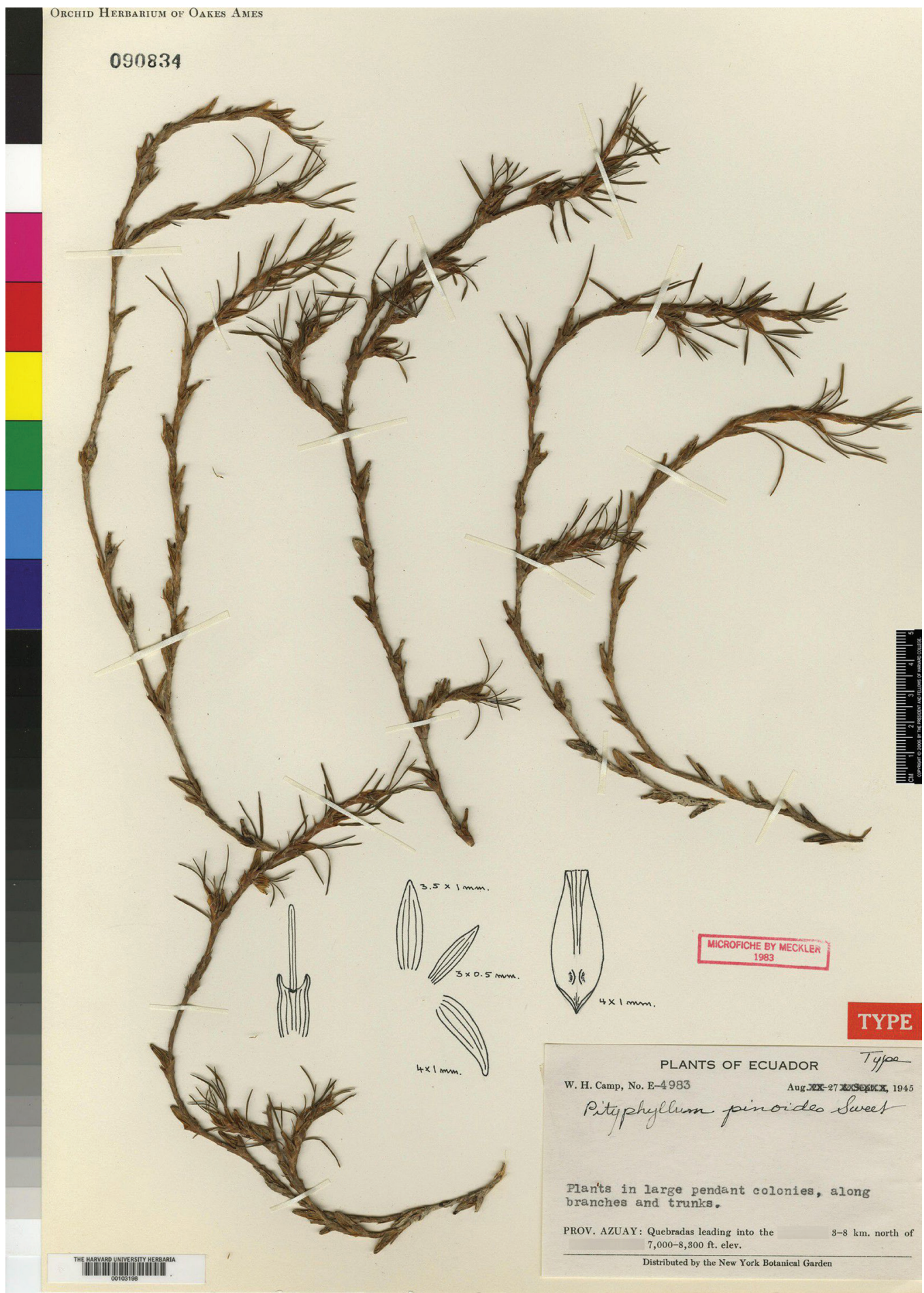

Figure 3. Holotype specimen of Pityphyllum pinoides H.R.Sweet, collected in Ecuador, Azuay, "Quebradas leading into the rio Collay, 3-8 km. north of Sevilla de Oro" by W. H. Camp in 1945. Reproduced with the kind permission of the Harvard University Herbarium. 


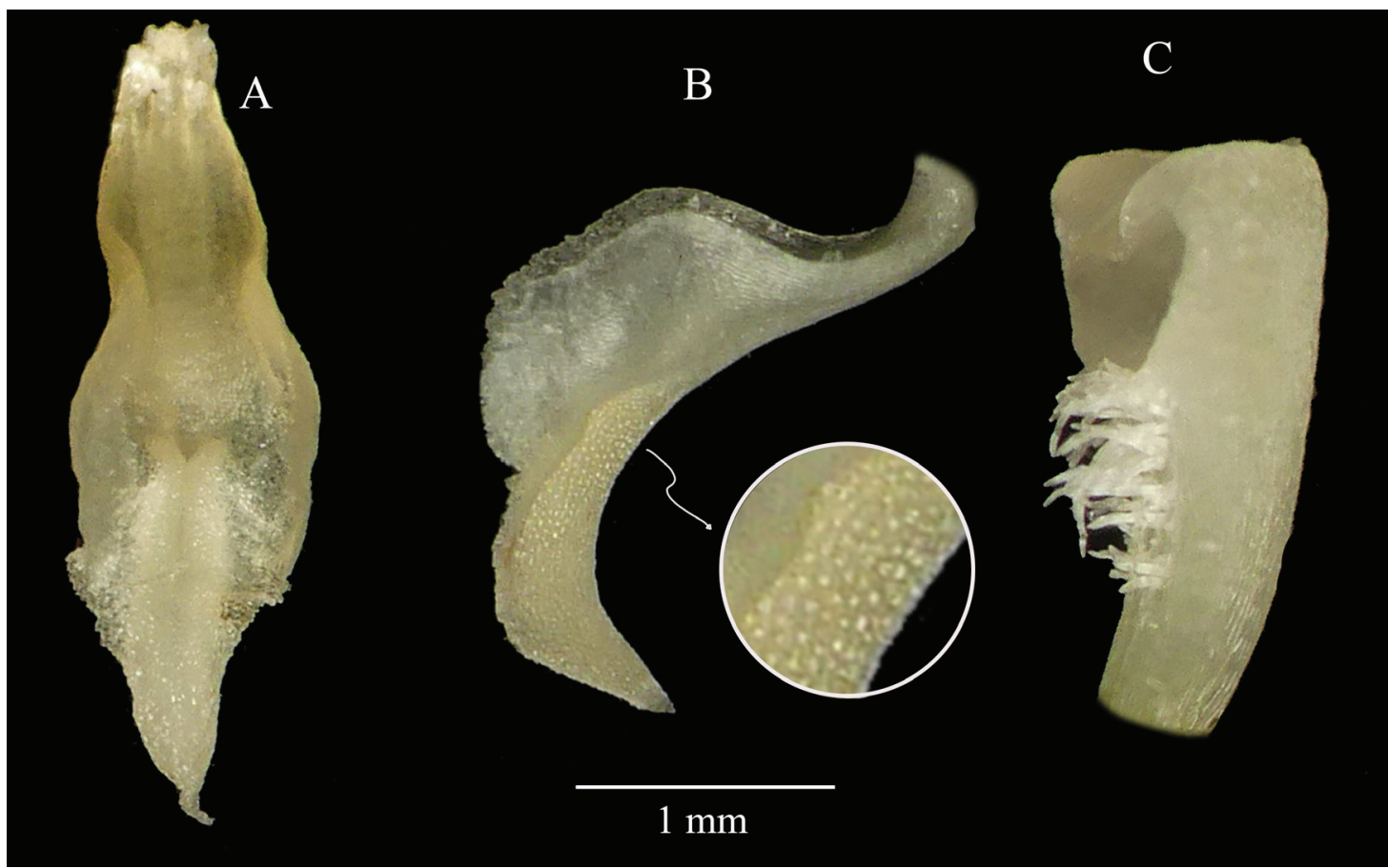

Figure 4. Column and lip in lateral view and lip ventral view of Pityphyllum mercedes-abarcae Vélez-Abarca \&

M.M.Jiménez. A. Two small parallel calluses in the apical third. B. Thin cell thickening in the abaxial part of the apical third of the lip. C. Elongated trichomes below the stigma. Photos by Marco M. Jiménez.

long, clinandrium with crenulated margin, glabrous, rostellum prominent, truncate, stigma bilobed, with elongate trichomes below. Anther cap apical, incumbent, yellowish-white, $7 \mathrm{~mm}$ wide. Pollinarium $0.6 \mathrm{~mm}$ long, with 4 obovate, yellow pollinia.

PARATyPe: Ecuador. Zamora Chinchipe: Cordillera del Cóndor flank, 04 June 2020, M. Jiménez 1013 (paratype: HUTPL!).

EPONYMY: Named after Mercedes Abarca, mother of the first author, in gratitude for her unconditional help, educational and moral teachings, and physical care.

Phenology: The species has been seen flowering in cultivation in March and April.

Distribution AND habitat: The new species is known so far from south-eastern Ecuadorian sandstone plateaus of the Cordillera del Cóndor, in the canton of El Pangui, province of Zamora-Chinchipe, at about $1300 \mathrm{~m}$ in elevation. Given this, it could be a species of restricted distribution, although it may be found in neighboring Peru. Until now, a small population has been found inhabiting the mature forests at the borders of the tepui walls, with most trees covered in epiphytes, bryophytes, and lichens. Generally, Pityphyllum mercedes-abarcae inhabits the upper canopy of the trees as a descending epiphyte. However, it can be found in the understory on fallen tree branches parallel to the ground. It has not been found in disturbed forests. Consequently, we believe this species is particularly vulnerable to environmental changes, as this species is commonly associated with bryophytes, which are only abundant in preserved areas.

Pityphyllum mercedes-abarcae (Fig. 2) is similar to other species of the Pityphyllum genus characterized by the elongated, branched rhizomes covered by imbricate bracts and lacking a column foot (Dodson 2004). The most similar species is P. pinoides (Fig. 3); the two differ at first glance by their size, which is three times longer than P. mercedes-abarcae (up to $8 \mathrm{~cm}$ long vs. $30 \mathrm{~cm}$ in P.pinoides); the pseudobulbs are separated by shorter intervals in P. mercedes-abarcae, up to $1.2 \mathrm{~cm}$ apart (vs. $2 \mathrm{~cm}$ apart), the pseudobulbs smaller, $0.5-0.8 \mathrm{~cm}$ long, (vs. $1.2 \mathrm{~cm} \mathrm{long),} \mathrm{the} \mathrm{leaves} \mathrm{are} \mathrm{acicular} \mathrm{(vs.} \mathrm{linear),}$ 


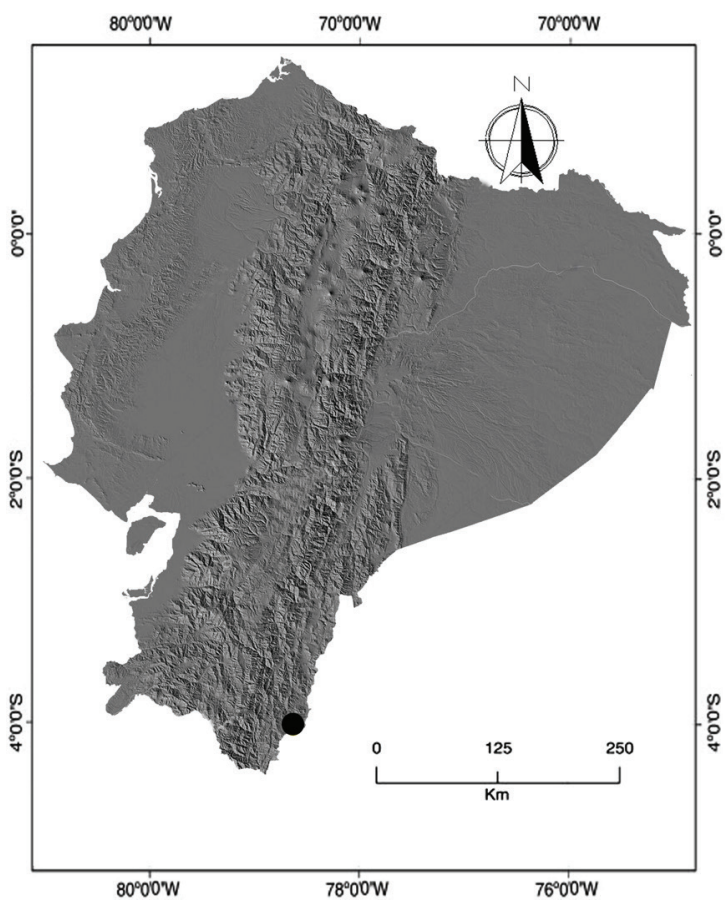

FIguRE 5. Distribution map of Pityphyllum mercedes-abarcae in Ecuador. Created by Leisberth Vélez Abarca.

narrower $0.5-0.7 \mathrm{~mm}$ (vs. $1 \mathrm{~mm}$ wide). The dorsal sepal is narrowly elliptical, attenuate at the base, concave in the proximal middle third and convex in the distal third, $3.1 \times 1.1 \mathrm{~mm}$ (vs. narrowly lanceolate-elliptical, concave dorsal sepal, $3.5 \times 1.0 \mathrm{~mm}$ ); the lateral sepals are elliptical, acute, constricted at the base, $3.0 \times$ $1.2 \mathrm{~mm}$ (vs. lateral sepals obliquely linear-lanceolate, subfalcate, up to $4.0 \times 1.0 \mathrm{~mm}$ ); the petals are spatulate, minutely apiculate at the apex, $2.9 \times 0.9 \mathrm{~mm}$ (vs. narrowly lanceolate-elliptic petals, acute, up to $3.0 \times$ $0.5 \mathrm{~mm}$ ). In addition, $P$. mercedes-abarcae has erose margins in the middle third, a feature not observed in $P$. pinoides. Lip flattened is square in the middle third, wedge in the basal third and acute in the apical third with two small parallel calluses, attenuate at the base (Fig.4A), the apex is acuminate, $2.9 \times 1.4 \mathrm{~mm}$ (vs. lip obovate, cuneate at the base, acute to sub-acuminate at the apex, up to $4.0 \times 1.0 \mathrm{~mm}), P$. mercedes-abarcae also has two unique characteristics that determine the species, presents a slight cell thickening in the abaxial part of the apical third of the lip (Fig. 4B) and elongated trichomes below the stigma in the abaxial side of the column (Fig. 4C).
Conservation status: Pityphyllum mercedes-abarcae has a very restricted distribution; so far only known from the canton of El Pangui (Fig. 5) in ZamoraChinchipe, Ecuador. To date, it was found in primary forests near a mining area so that the forests will likely be destroyed. Also, there is not a study on the abundance of plants in the population. Hence, its population density is unknown, and it is impossible to categorize the species using IUCN criteria. The fact that there is only one known population in an unprotected area suggests that the species will face serious conservation problems in the future.

AcKnOwLedgements. We acknowledge Lou Jost for helping with language corrections and other observations in this manuscript. To the Ministerio del Ambiente (MAE) of Ecuador for granting the research permits No. 037-2019-ICFLO-FAU-DPAZCH-UPN-VS/MA and 021-2019-IC-FLOFAU-DPAZCH-UPN-VS/M. We would like to thank Harvard University Herbaria for letting us use the image of the holotype of Pityphyllum pinoides. We thank Universidad de las Américas (UDLA) for funding orchid research in Ecuador. The authors also acknowledge the reviewers of this manuscript for helping with comments and corrections of this work.

\section{LITERATURE CITED}

Blanco, M.A., Carnevali, G., Whitten, W.M., Singer, R.B., Koehler, S., Williams, N.H., Ojeda, I., Neubig, K.M. \& Endara, L. (2007) Generic realignments in Maxillariinae (Orchidaceae). Lankesteriana, 7, 515-537.

Dathe, S. \& Dietrich, H. (2006). Comparative molecular and morphological studies in selected Maxillariinae orchids. Willdenowia, 36(1), 89-102.

Dodson, C. H. (2003). New orchid species and combinations from Ecuador 7. Orquideología, 22, 191-215.

Dodson, C. H. (2004). Pityphyllum. In: C. H. Dodson (Ed.), Native Ecuadorian Orchids: Vol. V: Rodriguezia-Zygosepalum (pp. 742-743). Quito: Imprenta Mariscal.

Dunsterville, G. C. K. \& Dunsterville, E. (1977). Some small Venezuelan orchids - 2. American Orchid Society Bulletin, 46, 792-797.

Ojeda, I., Carnevali, G., Williams, N. \& Whitten, W.M. (2003). Phylogeny of the Heterotaxis Lindley complex (Maxillariinae): evolution of the vegetative architecture and pollination syndromes. Lankesteriana, 7, 45-47.

Ruíz, H. \& Pavón, J. (1794). Flora peruvianae et chilensis prodromus. Madrid: Typis Gabrielis de Sancha.

Singer, R. \& Koehler, S. (2003). Towards a phylogeny of Maxillariinae orchids: Multidisciplinary studies 
with emphasis on Brazilian species. Lankesteriana, 7, 57-60.

Sitko, M., Tukallo, P. \& Górniak, M. (2006). Introduction to the phylogenetic analysis of Maxillaria Ruiz \& Pav. (Maxillariinae, Orchidaceae). Biodiversity: Research and Conservation, (3-4), 200-204.

Sweet, H. R. (1972). Orquídeas Andinas poco conocidas VI. Pityphyllum. Orquideología, 7, 203-214.

Whitten, M. W., Blanco, M. A. \& Williams N. H. (2006). Recircumscription of Pityphyllum (Orchidaceae: Maxillariinae). Orchids, 75(3), 452-456.
Whitten, M. W., Blanco, M. A., Williams, N. H., Koehler, S., Carnevali, G., Singer, R. B., Endara, L. \& Neubig, K.M. (2007). Molecular phylogenetics of Maxillaria and related genera (Orchidaceae: Cymbidieae) based on combined molecular data sets. American Journal of Botany, 94(11), 1860-1889.

Zambrano, B. J., Carnevali, G. \& Solano, R. (2020). Maxillaria purpureo-nigra (Orchidaceae: Maxillariinae), a new species from southwestern Ecuador belonging to Maxillaria sect. Rufescens. Phytotaxa, 477(2), 205-216. 